Catatan Penelitian

\title{
Nilai pH, Total Padatan Terlarut, dan Sifat Sensoris Yoghurt dengan Penambahan Ekstrak Bit (Beta vulgaris L.)
}

The Value of pH, Total Dissolved Solids, and Sensory Properties of Yoghurt with Addition Beet Extract (Beta vulgaris L.)

Nur Ismawati*, Nurwantoro, Yoyok Budi Pramono

Program Studi Teknologi Pangan, Fakultas Peternakan dan Pertanian, Universitas Diponegoro, Semarang

*Korespondensi dengan penulis (nurismawati19@yahoo.com)

Artikel ini dikirim pada tanggal 4 Juni 2016 dan dinyatakan diterima tanggal 01 Juli 2016. Artikel ini juga dipublikasi secara online melalui www.jatp.ift.or.id. Hak cipta dilindungi undang-undang. Dilarang diperbanyak untuk tujuan komersial.

Diproduksi oleh Indonesian Food Technologists ${ }^{\circledR}\left(\mathrm{C}_{2016}\right.$

\begin{abstract}
Abstrak
Penelitian ini bertujuan untuk mengetahui nilai $\mathrm{pH}$, total padatan terlarut, dan sifat sensoris yoghurt dengan penambahan ekstrak bit. Materi yang digunakan adalah susu skim cair, ekstrak bit, kultur bakteri asam laktat (BAL) yaitu Lactobbacillus bulgaricus, Streptococcus thermophillus, dan Lactobacillus acidophilus. Rancangan percobaan yang digunakan adalah Rancangan Acak Lengkap (RAL) dengan perlakuan penambahan ekstrak bit $0 \%, 1 \%, 2 \%$, $3 \%$, dan $4 \%$. Masing-masing perlakuan diulang sebanyak 4 kali. Hasil penelitian menunjukkan penambahan ekstrak bit memberikan perbedaan nyata $(\mathrm{P}<0,05)$ terhadap nilai $\mathrm{pH}$, total padatan terlarut, dan sifat sensoris yoghurt. Nilai pH menghasilkan angka $3,79-3,92$; total padatan terlarut $7,70-8,13^{\circ}$ Brix; dan semakin tinggi penambahan ekstrak bit yang digunakan menambah agak bau aroma tanah dan rasa lebih agak manis. Penambahan konsentrasi ekstrak bit terbaik yaitu $4 \%$.
\end{abstract}

Kata kunci : nilai $\mathrm{pH}$, total padatan terlarut, sifat sensoris, yoghurt, ekstrak bit

\section{Abstract}

The purpose of this research was to determined the $\mathrm{pH}$ value, total dissolved solids, and sensory properties of yoghurt with addition of beet extract. Material used in this research were liquid skimmed milk, beet extract, starter cultures of lactic acid bacteria (BAL) that were Lactobbacillus bulgaricus, Streptococcus thermophillus, and Lactobacillus acidophilus. The research showed that addition of the beet extract given significant $(P<0,05)$ the value of $\mathrm{pH}$, total dissolved solid, and sensory properties of yoghurt. The result obtained showed that the $\mathrm{pH}$ value ranged between 3.79 - 3.92; total dissolved solids $7.70-8.13^{\circ} \mathrm{Brix}$; and an addition in the taste and sweetness become increasingly concentrated. The additional of the best beet extract happens on $4 \%$.

Keywords: $\mathrm{pH}$, total dissolved solids, sensory properties, yoghurt, extract beet

\section{Pendahuluan}

Yoghurt merupakan salah satu produk fermentasi yang dihasilkan dengan menambahkan starter yoghurt aktif yang mengandung kultur campuran Lactobacillus bulgaricus (atau kadang-kadang acidophilus) dan Streptococcus thermophillus yang menghasilkan asam laktat selama proses fermentasi (Nwaoha et al., 2012). Asam laktat yang terbentuk akan menurunkan $\mathrm{pH}$ sekaOligus sebagai pengawet karena dalam kondisi asam bakteri patogen tidak dapat tumbuh. Asam laktat yang terbentuk berasal dari hasil pemecahan laktosa dalam susu. Ekstrak umbi bit mengandung gula yang diduga dapat menstimulasi pertumbuhan dan meningkatkan bakteri asam laktat (BAL) dalam menghasilkan asam laktat, sehingga mempengaruhi terhadap $\mathrm{pH}$. Salah satu kelebihan yoghurt karena sifat fungsionalitas terhadap kesehatan diantaranya yaitu mengatur kadar kolesterol dalam darah, memperlancar saluran pencernaan, membantu dalam meningkatkan pertumbuhan, antikanker, membantu penderita lactose intolerance, dan antidiare (Astawan, 2008). Sehingga dengan kelebihan yoghurt dan bit dapat mempengaruhi sifat fisiko kimia dan sensoris yoghurt $(\mathrm{pH}$, padatan terlarut, aroma tanah dan tingkat kemanisan) dapat diperbaiki atau diubah dengan penambahan bit (Beta vulgaris $\mathrm{L}$.) pada proses pembuatan yoghurt.

Bit kaya akan senyawa bioaktif yang bermanfaat seperti karotenoid, saponin, glisin betain, polifenol dan flavonoid (Vali et al., 2007). Selain itu mengandung mikronutrisi ( $\mathrm{Mg}, \mathrm{Na}, \mathrm{K}, \mathrm{Ca}$ dan Vitamin $\mathrm{C}$ ) yang tinggi, serat pangan serta zat besi, tetapi bit memiliki kandungan protein dan lemak yang rendah. Yoghurt kaya akan protein, lemak, kalsium, potassium, vitamin B (B1, B2, B6, asam nicotinic dan pantothenic) akan tetapi kekurangan zat besi, vitamin $\mathrm{C}$, karotenoid dan serat pangan (Gahruie et al., 2015). Dengan demikian, kombinasi dari ekstrak bit dan yoghurt akan meningkatkan pangan gizi dan fungsional karakteristik yoghurt. Bit memiliki sukrosa yang dapat ditambahkan pada yoghurt untuk memberikan rasa manis yoghurt. Kandungan serat yang terdapat pada bit dapat digunakan sebagai fortifikasi pada yoghurt yang dihasilkan dan diharapkan dengan penambahan bit dapat menambah serat terlarut. Yoghurt dengan tanpa penambahan rasa didominasi asam karena asam laktat yang dihasilkan oleh fermentasi. Maka dari itu, untuk penerimaan yang lebih baik, buah-buahan, bahan perasa atau bahan pemanis ditambahkan ke yoghurt 
untuk meningkatkan keseimbangan rasa dan menutupi sebagian rasa asetaldehid pada yoghurt.

Penelitian ini bertujuan untuk mengetahui perbedaan perlakuan penambahan konsentrasi ekstrak bit terhadap nilai $\mathrm{pH}$, total padatan terlarut, dan sifat sensoris (aroma tanah dan tingkat kemanisan) yoghurt dengan penambahan ekstrak bit. Manfaat penelitian ini yaitu untuk dapat melakukan penilaian terhadap penggunaan ekstrak bit dalam pembuatan yoghurt terhadap nilai $\mathrm{pH}$, total padatan terlarut, dan sifat sensoris yoghurt, serta untuk memberikan diversifikasi dari produk yoghurt produk pangan yang mempunyai nilai fungsional dan meningkatkan pangan gizi dari karakteristik yoghurt dengan menambahkan ekstrak bit.

\section{Materi dan Metode \\ Materi}

Bahan yang digunakan dalam penelitian ini adalah bit, air, susu skim cair, starter campuran $L$. bulgaricus, L. acidophilus, dan $S$. thermophillus, alkohol, aquadest, larutan buffer, dan susu UHT. Alat yang digunakan adalah juicer, plastik PE, botol kaca, panci, kompor, gelas beker, inkubator, freezer, cawan petri, pipet tetes, tabung reaksi, $\mathrm{pH}$ meter "HANNA instruments", refraktometer, viskometer, tisu, refrigerator, cup kecil, erlenmeyer, timbangan analitik, karet, corong, mikrotube, mikropipet kuning, mikropipet biru, plastik wrap, alumunium foil, gelas ukur, dan bunsen.

\section{Metode}

Penelitian dilakukan pada bulan September Oktober 2015. Perlakuan yang diterapkan terdiri dari tanpa penambahan ekstrak bit (TO), penambahan ekstrak bit $1 \%$ dari $500 \mathrm{ml}$ susu skim (T1), penambahan ekstrak bit $2 \%$ dari $500 \mathrm{ml}$ susu skim (T2), penambahan ekstrak bit $3 \%$ dari $500 \mathrm{ml}$ susu skim (T3), dan penambahan ekstrak bit $4 \%$ dari $500 \mathrm{ml}$ susu skim (T4). masing-masing perlakuan diulang sebanyak 4 kali.

Penelitian terdiri dari beberapa langkah yaitu pembuatan ekstrak bit, pembuatan starter kerja yoghurt, pembuatan yoghurt dengan penambahan ekstrak bit dan pengujian parameter yang meliputi nilai $\mathrm{pH}$, total padatan terlarut dan sifat sensoris (aroma tanah dan tingkat kemanisan). Umbi bit diambil ekstraknya dengan menggunakan juicer untuk didapatkan hasil ekstrak bit. Pembuatan starter kerja digunakan dengan mencampurkan bibit bubuk yoghurt dengan aquades hingga diperoleh starter kerja yoghurt (Harjiyanti et al., 2013). Mekanisme pembuatan yoghurt dengan penambahan ekstrak bit yaitu susu skim cair masing-masing sebanyak $500 \mathrm{ml}$ yang telah ditambahkan dengan ekstrak bit sebanyak 0\%, 1\%, 2\%, $3 \%$, dan $4 \%$ (sesuai perlakuan) dan di pasteurisasi pada $73{ }^{\circ} \mathrm{C}$ selama 15 detik, lalu suhunya diturunkan sampai $43{ }^{\circ} \mathrm{C}$. Susu hasil pasteurisasi kemudian diinokulasi dengan starter BAL sebanyak $5 \%$, selanjutnya diinkubasi selama 4 jam pada suhu $43^{\circ} \mathrm{C}$ (Legowo et al., 2009 dengan modifikasi). Parameter pengujian yoghurt yaitu pengujian nilai $\mathrm{pH}$ dengan $\mathrm{pH}$ meter(AOAC, 1995), total padatan terlarut dengan refraktometer (SNI, 2004) dan sifat sensoris (aroma tanah dan tingkat kemanisan) menggunakan panelis (Setyaningsih et al., 2010).

\section{Pengujian Nilai pH}

Pengukuran $\mathrm{pH}$ (derajat asam) dengan $\mathrm{pH}$ meter "HANNA instruments" yang dikalibrasi dengan larutan buffer $\mathrm{pH} 4$ dan 7 sebelum digunakan. Pengukuran sampel dilakukan dengan sebanyak $20 \mathrm{ml}$ diambil, kemudian elektroda dibilas dengan aquades. Elektroda dikeringkan dengan tisu kemudian dicelupkan dalam sampel. Elektroda dibiarkan tercelup beberapa saat. Nilai yang terbaca adalah nilai $\mathrm{pH}$ yang telah stabil (AOAC, 1995).

\section{Pengujian Total Padatan Terlarut}

Pengukuran total padatan terlarut menggunakan refractometer menurut SNI 01-3546-2004. Total kandungan padatan terlarut dari ekstrak bit dan yoghurt dengan penambahan ekstrak bit ditentukan dengan menggunakan refraktometer genggam digital (Model: PAL-1, Atago co, Ltd, Tokyo, Jepang) pada $25^{\circ} \mathrm{C}$ dan dilakukan kalibrasi menggunakan aquades, sebanyak 1-2 sampel dimasukkan pada prisma refraktometer dan jumlah kandungan padatan terlarut dinyatakan sebagai ${ }^{\circ}$ Brix.

\section{Pengujian Sensoris}

Pengujian sensoris dilakukan oleh 25 orang panelis agak terlatih. Panelis dipilih secara acak yang diminta untuk menilai tingkat kemanisan, aroma tanah, dan citarasa asam yoghurt dengan penambahan ekstrak bit. Metode yang digunakan adalah dengan mempersiapkan sampel terlebih dahulu dengan ditempatkan pada cup kecil $50 \mathrm{ml}$. Tabel uji disediakan berupa form kuisioner uji tingkat aroma tanah yoghurt dengan rentang nilai 1 sampai 5 dengan nilai 1 yaitu sangat tidak bau tanah, nilai 2 yaitu tidak bau tanah, nilai 3 yaitu agak bau tanah, nilai 4 yaitu bau tanah, dan nilai 5 yaitu sangat bau tanah. Uji tingkat kemanisan yoghurt dengan rentang nilai 1 sampai 5 dengan nilai 1 yaitu sangat tidak manis, nilai 2 yaitu tidak manis, nilai 3 yaitu agak manis, nilai 4 yaitu manis, dan nilai 5 yaitu sangat manis (Setyaningsih et al., 2010).

\section{Analisis Data}

Data yang diperoleh dari pengujian nilai $\mathrm{pH}$ dan total padatan terlarut yoghurt diolah dengan Analisis of Varians (ANOVA) pada taraf $5 \%$ karena sebaran datanya normal untuk mengetahui perbedaan perlakuan konsentrasi ekstrak bit terhadap nilai $\mathrm{pH}$ dan total padatan terlarut. Apabila terdapat perbedaan nyata maka dilanjutkan dengan uji Wilayah Ganda Duncan (Duncan's Multi Range Test). Uji Duncan ini digunakan untuk mengetahui perlakuan konsentrasi yang menunjukkan perbedaan secara nyata. Pengujian sifat sensoris (aroma tanah dan tingkat kemanisan) diuji dengan menggunakan uji Kruskal-Wallis, dan apabila terdapat perbedaan nyata maka dilanjutkan ke uji Mann-Whitney untuk mengetahui perlakuan konsentrasi ekstrak bit yang menunjukkan perbedaan secara nyata. 
Perolehan data diolah dengan bantuan komputer program SPSS 16.0 for windows.

\section{Hasil dan Pembahasan \\ Nilai $\mathrm{pH}$}

Berdasarkan Tabel 1, nilai pH yoghurt dengan penambahan ekstrak bit menunjukkan adanya perbedaan nyata penambahan ekstrak bit terhadap $\mathrm{pH}$ yoghurt. Rata-rata $\mathrm{pH}$ akhir yoghurt berkisar antara 3,79 - 3.92 dengan waktu fermentasi selama 6 jam. Kisaran $\mathrm{pH}$ tersebut merupakan akibat dari Streptoccus yang menurunkan $\mathrm{pH}$ menjadi 5,0 - 5,5 yang kemudian dilanjutkan dengan aktivitas Lactobacillus yang menurunkan pH menjadi 3,8 - 4,4 (Rahman et al., 1992).

Dalam penelitian ini, rata-rata nilai $\mathrm{pH}$ yoghurt yang ditambahkan dengan ekstrak bit 1\% dan $2 \%$ terlihat lebih rendah dari kontrol (Tabel 1). Dukungan dari umbi bit yang memiliki karbohidrat berupa gula sukrosa sebagai sumber energi bagi berlangsungnya bakteri untuk proses fermentasi. Hal ini sesuai dengan Icier et al. (2015) bahwa tersedianya karbohidrat sebagai sumber energi menyebabkan peningkatan metabolisme aktivitas oleh bakteri $L$. acidophilus yang memberikan kontribusi terhadap penurunan $\mathrm{pH}$. Sedangkan $\mathrm{pH}$ yoghurt dengan penambahan ekstrak bit $3 \%$ dan $4 \%$ terlihat berada diatas kontrol dan hasil $\mathrm{pH}$ yoghurt dengan penambahan ekstrak bit $1 \%, 2 \%, 3 \%$, $4 \%$, dan $5 \%$ terlihat mengalami peningkatan nilai $\mathrm{pH}$. Hal tersebut terjadi diduga karena efek penghambatan oleh gula-gula sederhana (sukrosa) yang terkandung dalam umbi bit karena habitat asli dari BAL yaitu memecah laktosa dan hanya memanfaatkan laktosa sebagai sumber karbon dan sumber energi.

Menurut Patrick et al. (2004) BAL memanfaatkan laktosa dan menghasilkan asam laktat sebagai zat metabolit karena laktosa merupakan sumber utama karbon dan sumber energi bagi BAL terutama oleh spesies bakteri $S$. thermophilus. Ditambahkan oleh Kiros et al. (2016) menyatakan bahwa meningkatnya nilai $\mathrm{pH}$ yang ditambahkan oleh ekstrak bit adalah karena aktivitas yang rendah oleh bakteri asam laktat selama masa inkubasi dibandingkan dengan kontrol yang memiliki kandungan solid non fat (SNF) atau padatan bukan lemak dan memiliki kadar laktosa dalam susu yang lebih tinggi.

\section{Total Padatan Terlarut}

Tabel 1. menunjukkan bahwa perlakuan penambahan ekstrak bit memilki perbedaan nyata $(\mathrm{P}<0,05)$ terhadap total padatan terlarut. Total padatan terlarut yang diperoleh yaitu antara 7,70 - 8,10 ${ }^{\circ}$ Brix. Proses fermentasi bakteri asam laktat menghasilkan metabolit berupa asam laktat. Menurut Fardiaz (2003) metabolit tersebut akan terseksresikan keluar sel dan akan terakumulasi dalam cairan fermentasi. Sisa hasil total gula, asam laktat, dan asam organik yang terbentuk terhitung sebagai total padatan terlarut. Komponen padatan terlarut terdiri dari total gula. pigmen, asam-asam organik, dan protein.
Berdasarkan hasil penelitian yang telah dilakukan semakin tinggi perlakuan penambahan ekstrak bit maka total padatan terlarutnya juga semakin tinggi. Peningkatan ekstrak bit menyebabkan jumlah total padatan terlarut (TPT) yang dihasilkan semakin meningkat pula. Selama berlangsungnya proses fermentasi laktosa dan sukrosa akan dirombak oleh kultur starter. Menurut Sintasari et al. (2014) sisa laktosa, sukrosa dan asam-asam organik lain tersebut yang terhitung sebagai total padatan terlarut. Sehingga semakin banyak penambahan dengan ekstrak bit akan meningkatkan total padatan terlarutnya. Asam laktat termasuk asam organik yang merupakan salah satu jenis total padatan terlarut selain gula, pigmen, dan vitamin.

Tabel 1. Nilai Rata-rata Nilai $\mathrm{pH}$ dan Total Padatan Terlarut Yoghurt dengan Perlakuan Penambahan Ekstrak Bit

\begin{tabular}{ccc}
\hline Perlakuan & Nilai pH & $\begin{array}{c}\text { Total Padatan } \\
\text { Terlarut }\end{array}$ \\
\hline T0 & $3,89 \pm 0,37^{\mathrm{b}}$ & $7,70 \pm 0,20^{\mathrm{a}}$ \\
T1 & $3,79 \pm 0,59^{\mathrm{a}}$ & $7,90 \pm 0,09^{\mathrm{ab}}$ \\
T2 & $3,88 \pm 0,77^{\mathrm{b}}$ & $8,01 \pm 0,63^{\mathrm{bc}}$ \\
T3 & $3,92 \pm 0,52^{\mathrm{b}}$ & $8,13 \pm 0,16^{\mathrm{c}}$ \\
T4 & $3,92 \pm 0,71^{\mathrm{b}}$ & $8,10 \pm 0,14^{\mathrm{bc}}$ \\
\hline
\end{tabular}

Keterangan: Superskrip huruf kecil yang berbeda pada baris rata-rata menunjukkan perbedaan nyata $(\mathrm{P}<0,05)$

Tabel 2. Rata-rata Sifat Sensori Yoghurt dengan Perlakuan Penambahan Ekstrak Bit

\begin{tabular}{lcc}
\hline Perlakuan & Aoma Tanah & $\begin{array}{c}\text { Tingkat } \\
\text { Kemanisan }\end{array}$ \\
\hline T0 & $1,24 \pm 0,44^{\mathrm{a}}$ & $2,00 \pm 0,64^{\mathrm{a}}$ \\
T1 & $1,96 \pm 0,54^{\mathrm{b}}$ & $2,04 \pm 0,61^{\mathrm{a}}$ \\
T2 & $2,64 \pm 0,50^{\mathrm{c}}$ & $2,20 \pm 0,64^{\mathrm{a}}$ \\
T3 & $3,12 \pm 0,53^{\mathrm{d}}$ & $2,96 \pm 0,74^{\mathrm{b}}$ \\
T4 & $3,16 \pm 0,47^{\mathrm{de}}$ & $2,92 \pm 1,00^{\mathrm{bc}}$ \\
\hline
\end{tabular}

Keterangan: Superskrip huruf kecil yang berbeda pada baris rata-rata menunjukkan perbedaan nyata $(\mathrm{P}<0,05)$

Total padatan terlarut dalam ekstrak bit adalah sebesar $6{ }^{\circ}$ Brix yang menunjukkan bahwa isi padatan terlarut adalah gula dan asam organik. Menurut Manjunatha dan Raju (2015) kepadatan dan aktivitas air dalam ekstrak bit masing-masing adalah sekitar $1024,4 \mathrm{~kg} / \mathrm{m} 3$ dan 0,988 . Total padatan meningkat seiring dengan meningkatnya presentase ekstrak bit. Hal ini dikarenakan bit memiliki sejumlah padatan terlarut sehingga setelah ditambahakan ke yoghurt, padatan terlarut dalam yoghurt meningkat. Hal tersebut sesuai dengan pendapat Osundahusi et al. (2007) yang menyatakan bahwa kandungan gula tinggi yang tinggi dari buah-buahan atau lainnya yang ditambahkan ke yoghurt telah berkontribusi terhadap komponen padatan terlarut yang lebih tinggi.

\section{Aroma Tanah}

Berdasarkan rata-rata hasil penelitian aroma tanah yoghurt dengan penambahan ekstrak bit, seiring dengan level pemberian ekstrak bit menambah tingkat aroma tanah pada yoghurt. Aroma atau bau suatu produk pangan menentukan kenikmatan pangan tersebut. Penilaian aroma suatu produk pangan tidak 
terlepas dari fungsi indera pembau. Hal sesuai menurut Winarno (2004) yang menyatakan bahwa bau yang diterima oleh hidung dan otak lebih banyak merupakan campuran empat bau yaitu asam, tengik, harum, dan hangus. Aroma dan rasa yang dihasilkan dari umbi bit disebabkan oleh senyawa volatil, senyawa tersebut dipancarkan karena jaringan terluka, terpotong, dipanaskan atau dihancurkan.

Perlakuan yoghurt T0 (0\%) atau kontrol yang dihasilkan adalah sangat tidak bau. Hal ini dikarenakan tidak ada penambahan ekstrak bit sedikitpun pada yoghurt sehingga aroma tanah yang dihasilkan tidak ada. Penambahan ekstrak bit $1 \%$ memiliki nilai rata-rata terendah yaitu 1,96 yaitu dengan kriteria sangat tidak bau sampai tidak bau. Sedangkan untuk rata-rata nilai aroma tanah paling tinggi adalah $4 \%$ yaitu 3,16 dengan kriteria agak bau tanah. Aroma tanah yang terkandung pada bit disebabkan oleh suatu senyawa yang terkandung, sehingga semakin banyak penambahan ekstrak bit yang ditambahkan maka semakin tinggi pula tingkat aroma bau tanah yoghurt tersebut. Sesuai dengan Lu et al. (2003) yang menyatakan bahwa aroma tanah pada bit disebabkan oleh suatu senyawa yang terdapat di bit yaitu geosmin dan beberapa senyawa pirazin saat menambahkan ekstrak bit. Geosmin merupakan senyawa metabolit sekunder yang bersifat aromatik. Menurut Lu et al. (2003) bahwa senyawa organik tersebut dihasilkan oleh mikroba dalam tanah, geosmin mengeluarkan bau seperti aroma tanah atau seperti bau yang dihasilkan ketika hujan turun dan mengenai permukaan bumi. Hidung manusia sangat sensitif terhadap geosmin. Beberapa orang tidak menyukai aroma tanah tersebut sedangkan yang lainnya menyukai.

\section{Tingkat Kemanisan}

Berdasarkan hasil penelitian yang dilakukan tersebut didapatkan hasil bahwa kontrol mempunyai nilai 2,00 yang berarti memiliki kriteria tidak manis. Begitu pula dengan tingkat kemanisan yoghurt dengan penambahan ekstrak bit $1 \%$ dan $2 \%$ yang mempunyai nilai masing-masing sebesar 2,04 dan 2,20 dengan kriteria tidak manis. Sedangkan hasil yang berbeda ditunjukkan oleh yoghurt dengan penambahan ekstrak bit $3 \%$ dan $4 \%$ yaitu dengan nilai 2,96 dan 2,92 dengan kriteria tidak manis sampai agak manis. Hal tersebut mengindikasikan bahwa penambahan ekstrak bit dapat menambah rasa manis pada yoghurt. Kandungan gula dalam bit diduga bertanggung jawab terhadap hal tersebut yang mempengaruhi penilaian panelis terhadap tingkat kemanisan. Hal ini sesuai dengan Andarwulan dan Faradilla (2012) bahwa tanaman bit dibudidayakan terutama untuk produksi gula karena umbi bit mengandung gula sukrosa dalam kadar yang tinggi, sehingga digunakan sebagai pemanis. Sesuai dengan hasil penelitian kadar gula dalam bit mengandung sekitar 6\%. Menurut Drake et al. (2001) menyatakan bahwa rasa gula yang manis memiliki efek yang besar dengan penilaian konsumen terhadap rasa yoghurt.
Berdasarkan Tabel 2 terlihat bahwa yoghurt dengan penambahan ekstrak bit $1 \%$ sampai $4 \%$ masih menghasilkan yoghurt dengan kriteria tidak manis sampai agak manis. Yoghurt yang dihasilkan belum mendapati kriteria manis ataupun sangat manis. Hal tersebut berkaitan dengan kandungan gula sukrosa yang terdapat dalam bit memilki nilai rasa manis yang berbeda dengan glukosa dan fruktosa. Hal ini sesuai dengan Belitz et al. (2009) yang menyatakan bahwa glukosa memiliki nilai rasa manis $69 \%$ dari sukrosa, sedangkan fruktosa memiliki nilai rasa manis $114 \%$ dari sukrosa. Hal ini ditambahkan oleh Sintasari et al. (2014) bahwa sukrosa yang pada fungsi utama sebagai pemberi rasa manis yang juga dapat memberikan nutrisi pada bakteri asam laktat secara optimal agar bakteri tersebut mampu menghasilkan rasa yang pas dan tidak terlalu masam / khas akibat pembentukan asam laktat dan asam-asam organik lain sebagai hasil dari metabolitnya sehingga menimbulkan kombinasi yang pas bagi panelis saat menguji coba produk yoghurt dengan penambahan ekstrak bit ini.

\section{Kesimpulan}

Berdasarkan hasil penelitian yang telah dilakukan dapat disimpulkan bahwa semakin besar penambahan ekstrak bit maka semakin menaikkan nilai $\mathrm{pH}$ dan total padatan terlarut. Yoghurt dengan penambahan ekstrak bit cenderung agak bau tanah (kriteria sangat tidak bau hingga agak bau), dengan tingkat kemanisan cenderung agam manis (kriteria tidak manis hingga agak manis).

\section{Daftar Pustaka}

Andarwulan, N. dan F. Faradilla. 2012, Pewarna Alami Untuk Pangan. Seafast Center. Institut Pertanian Bogor. Bogor.

AOAC. 1995. Official Methods of Analisys Chemist. Vol. 1A. AOAC Inc., Washington.

Astawan, M. 2008. Sehat dengan Hidangan Hewani. Penebar Swadaya.

SNI 01-3546. 2004. TSS Gravimetri. Standar Nasional Indonesia. Jakarta.

Belitz, H. D., W. Grosch., dan P. Schieberle. 2009. Food chemistry. Berlin, Germany: Springer Verlag.

Drake, M. A., P. D. Gerard, and Q. Chen. 2001. Effects of sweetener, sweetener concentration, and fruit flavor on sensory properties of soy fortified yogurt. Journal of Sensory Studies. 16 (4): 393 405.

Fardiaz, S. 2003. Mikrobiologi Pangan. Gramedia Pustaka Utama. Jakarta.

Gahruie, H. H., M. H. Eskandaria., G. Mesbah., and M. A. Hanifpour. 2015. Scientific and technical aspects of yogurt fortification: a review. Food Science and Human Wellness. 4: 1-8.

Harjiyanti, M. D., Y. B. Pramono dan S. Mulyani. 2013. Total asam, viskositas, dan kesukaan pada yoghurt drink dengan sari buah manga (Mangifera indica) sebagai perisa alami. J. Apl. Teknologi Pangan. 2 (2): 104-107. 
Icier, F., G. T. Gunduz., B. Yilmaz dan Z. Memeli. 2015. Changes on some quality characteristics of fermented soy milk beverage with added apple juice. J. Food Sciend and Technology. 63: 57-64.

Kiros, E., E. Seifu., G. Bultosa., and W.K. Solomon. 2016. Effect of carrot juice and stabilizer on the pHysicochemical and microbiological properties of yoghurt. J. Food Science and Technology. 69: 191-196.

Legowo, A. M., Kusrahayu dan S. Mulyani. 2009. IImu dan Teknologi Susu. Badan Penerbit Universitas Diponegoro. Semarang.

Lu, G., C. G. Edwards., J. K. Fellman., D. S. Mattinson and J. Navazio. 2003. Biosynthetic origin of geosmin in red beets (Beta vulgaris L.). J. Agric. Food Chem. 51: 1026-1029.

Majunantha, S, S., dan P. S. Raju. 2015. Rheological characteristics of reconstituted spray dried beetroot (Beta vulgaris L.) juice powder at different solid content, temperatures and carrier materials. International Food Research Journal. 22 (6): 2333-2345.

Nwaoha, M., I. Elizabeth and N. G. Onyinyechi. 2012. Production and evaluaton of yoghurt flavoured with beetroot (beta vulgaris L.). Journal of Food Science and Engineering. 2: 583-592.

Osundahunsi, O, F., Amosu, D. and B.O.T. Ifesan, 2007. Quality Evaluation and Acceptability of
Soy-yoghurt with Different Colours and Fruit Flavours. American Journal of Food Technology. 2: $273-280$.

Patrick, T. C., V. D. Bogaard, P. Hols, O. P. Kuipers, M. Kleerebezem, W. M. de Vos. 2004. Sugar utilization and conservation of the gal-lac gene cluster in S. thermophilus. Systematic and Applied Microbiology. 27 (1): 10-17.

Rahman, A., S. Fardiaz., W. P. Rahaju, Suliantari dan C. C. Nurwitri. 1992. Bahan Pengajaran Teknologi Fermentasi Pusat Antar Universitas Pangan dan Gizi. Institute Pertanian Bogor.

Setyaningsih, D., A. Apriyantono, M. P. Sari. 2010. Analisis Sensori untuk Industri Pangan dan Agro. IPB Press. Bogor.

Sintasari, R. A., J. Kusnadi, dan D.W. Ningtyas. 2014. Pengaruh penambahan konsentrasi susu skim dan sukrosa terhadap karakterisik minuman probiotik sari beras merah. J. Pangan dan Agroindustri. 2 (3): 65-75.

Vali, L., E. Stevanofits-Banyai, Szentmihalyi, K. Febel, H. Sardi, E. Lugasi, I. Koscis and A. Blazovics. 2007. Liver-protecting effects of table beet (Beta vulgaris var. Rubra) during ischemia-reperfusion. J. Nutrition 23: 172-178.

Winarno, F. G. 2004. Kimia Pangan dan Gizi. Gramedia. Jakarta. 